\title{
Pharmaceutical Equivalent Study of Losartan Potassium Formulation available in Karachi, Pakistan
}

\author{
Hameed A*, Naveed S, Abbas SS and Qamar F \\ Department of Pharmacy, Jinnah University for Women, 5C, Nazimabad, Karachi 74600, Pakistan
}

\begin{abstract}
The purpose of this study is to check pharmaceutical equivalence of altered brands of Losartan Potassium tablets available in Karachi, Pakistan. Two different brands of Losartan Potassium tablets $(50 \mathrm{mg})$ were investigated in the study. Five Quality Control (QC) parameters: Weight variation, thickness test, hardness, friability and disintegration tests were carried out as specified by BP/USP (British Pharmacopoeia and United State Pharmacopoeia). The result of study revealed that all above mentioned tests are in accordance with BP/USP. Both brands of Losartan Potassium tablets are Pharmaceutical Equivalent.
\end{abstract}

Keywords: Losartan potassium; Weight variation; Hardness; Thickness; Friability; Disintegration

\section{Introduction}

Losartan is a phenyl tetrazole deputize for imidazole compound and it is an Angiotensin Receptor Blocker II (ARB II) type I antagonist and it is used in the treatment of hypertension. Administration of Losartan results in a decrease Total Peripheral Resistance (TPR) and cardiac venous return [1]. Their pharmacologic effect is similar to that of the Angiotensin Converting Enzyme (ACE) inhibitors, since they also produce the arteriolar as well as venous dilation and blocks aldosterone secretion, thus lowers the blood pressure, salt content and water retention [2]. It is the prototypic ARB. Their pharmacologic effects are similar to the ACE inhibitors [3]. They decrease the nephrotoxicity of diabetes and makes attractive therapy in hypertensive diabetics [4]. Losartan is specific or selective type I Angiotensin II receptor (AT1) antagonist. They block receptor as a result decrease in blood pressure (Rennin-Angiotensin-Aldosterone System (RAAS)) [5]. Losartan inhibit the binding of angiotensin II to type I in tissue (kidney and adrenal glands) [6]. Losartan and its active metabolites E-3174 are more potent than losartan inhibition (angiotensin II to type I) and causes vasodilation (normally AT1 $\rightarrow$ vasoconstriction + aldosteron) decrease in sodium as well as water retention but increases excretion [6]. Protein binding of losartan is $99.7 \%$ (primarily albumin) and bioavailability is 25-35\% [7]. The appearance of losartan potassium is white or may be off white crystalline powder where its melting point is between $263-265^{\circ} \mathrm{C}$ and it is freely soluble in water. Molecular mass of losartan potassium is 462.01 [8]. Its indications are: mild to severe hypertension, diabetic nephropathy reducing risk of stroke in people with heart disease [9]. Hypergranulosis and hyperkeratosis be developed during its treatment with losartan for arterial hypertension. Long term use of losartan potassium develops angioedema [2].

\section{QC Parameter Testing}

All QC parameters and physical appearance testing of altered brands of Losartan Potassium were carried out. Variation in weight was checked on A.N.D Electronic Balance FX-400. For which 20 tablets of each brand are selected randomly. The percentage weight variation from average tablet weights was calculated. In the weight variation test, the tablet should be within the limits of the percentage deviation allowed by BP. The degree of compaction of 10 tablet of each brand is assessed by measuring the thickness of tablets, using Vernier Caliper. Hardness of all the brands is checked on MH-1, Hardness Tester of
Galvano Scientific. The hardness value of each tablet was evaluated and average value was calculated and compared. No. of tablets were calculated to perform friability test of each brand of ketotifen by subjecting to a uniform tumbling motion for specified period of time i.e., 25 rotation/min for $4 \mathrm{~min}$ in Fb-1004 Curio Company and the weight loss is determined. Disintegration test for all brands was done on Curro Model No Ds-0702. A $900 \mathrm{ml}$ beaker was filled with distilled water and temperature was maintained at $37 \pm 2^{\circ} \mathrm{C} .6$ tablets of each brand were selected randomly and placed into the basket rack assembly and connected to the disintegration apparatus. The disintegration time for each brand is compared with the Pharmacopoeia limit specified by BP.

\section{Result and Discussion}

The purpose of this research work was to compare and evaluate the quality standards of commercially available two brands of Losartan Potassium Tablet in Karachi, Pakistan. Losartan Potassium Tablets (50 mg) were evaluated comparatively for their physical parameters. Weight variation test of Losartan Potassium tablets proved statistically that all the tablets were in accordance to the BP/USP requirements as shown in the Tables 1-3. Thickness of all tablets of Losartan Potassium including standard deviation, average weight, upper \& lower limits are in accordance with BP/USP as shown in the Tables 4 and 5. Hardness test of Losartan Potassium tablets were found within the BP/USP limits. Both the brands of Losartan Potassium passed the hardness test i.e., average hardness of both brands was found to be greater than 4 $\mathrm{kg}$ but less than $10 \mathrm{~kg}$. Data of hardness test is given in Tables 6 and 7. Friability of both brands of Losartan Potassium tablets was less than $1 \%$. Therefore, it is in compliance with the BP/USP standards. Its data is given in Table 8. Disintegration time of both the brands of naproxen is observed. Both the tablets disintegrated within 20 min which are in under the USP limits i.e., within 60 min for coated tablets. Data of disintegration test is shown in Table 9.

${ }^{*}$ Corresponding author: Hameed A, Faculty of Pharmacy, Jinnah University for Women, 5C, Nazimabad, Karachi 74600, Pakistan, Tel: 922136620859; E-mail: asra_hameed1@hotmail.com

Received October 11, 2016; Accepted November 08, 2016; Published November 21, 2016

Citation: Hameed A, Naveed S, Abbas SS, Qamar F (2016) Pharmaceutical Equivalent Study of Losartan Potassium Formulation available in Karachi, Pakistan J Bioequiv Availab 8: 283-284. doi: 10.4172/jbb.1000310

Copyright: (c) 2016 Hameed A, et al. This is an open-access article distributed under the terms of the Creative Commons Attribution License, which permits unrestricted use, distribution, and reproduction in any medium, provided the original author and source are credited. 
Citation: Hameed A, Naveed S, Abbas SS, Qamar F (2016) Pharmaceutical Equivalent Study of Losartan Potassium Formulation available in Karachi, Pakistan. J Bioequiv Availab 8: 283-284. doi: 10.4172/jbb.1000310

\section{Conclusion}

Both the two brands of Losartan Potassium are pharmaceutical equivalents. No Difference was detected in weight variation testing, thickness testing, hardness testing, friability testing and disintegration testing of tablets.

\begin{tabular}{|c|c|c|}
\hline No. of Tablets & Qsartan (g) & Losartan (g) \\
\hline 1 & 155 & 175 \\
\hline 2 & 145 & 167 \\
\hline 3 & 153 & 171 \\
\hline 4 & 152 & 176 \\
\hline 5 & 149 & 174 \\
\hline 6 & 151 & 164 \\
\hline 7 & 150 & 173 \\
\hline 8 & 157 & 177 \\
\hline 9 & 160 & 172 \\
\hline 10 & 150 & 172 \\
\hline 11 & 150 & 176 \\
\hline 12 & 150 & 173 \\
\hline 13 & 155 & 170 \\
\hline 14 & 151 & 167 \\
\hline 15 & 153 & 172 \\
\hline 16 & 153 & 175 \\
\hline 17 & 143 & 168 \\
\hline 18 & 149 & 176 \\
\hline 19 & 152 & 172 \\
\hline 20 & 150 & 168 \\
\hline
\end{tabular}

Table 1: Weight of 20 tablets (randomly selected) of different brands.

\begin{tabular}{|c|c|c|c|c|}
\hline \multirow{2}{*}{ Tablets } & Average (g) & $\begin{array}{c}\text { Standard } \\
\text { deviation }\end{array}$ & Upper limit & Lower limit \\
\hline Qsartan & 151 & 3.7 & 162.1 & 139.9 \\
\hline Losartan & 171.9 & 3.61 & 182.73 & 161.07 \\
\hline
\end{tabular}

Table 2: Statistical weight variations.

\begin{tabular}{|c|c|c|c|}
\hline Tablets & Result (g) & BP/USP Specification & $\begin{array}{c}\text { Deviation from BP/USP } \\
\text { Specification }\end{array}$ \\
\hline Qsartan & 151 & Deviation should be $\pm 7.5 \%$ & Within specified limit \\
\hline Losartan & 171.9 & Deviation should be $\pm 7.5 \%$ & . \\
\hline
\end{tabular}

Table 3: Weight variation test.

\begin{tabular}{|c|c|c|}
\hline Number of sample & Qsartan & Losartan \\
\hline 1 & 6 & 9 \\
\hline 2 & 9 & 6 \\
\hline 3 & 9 & 8 \\
\hline 4 & 6 & 9 \\
\hline 5 & 7 & 9 \\
\hline 6 & 9 & 9 \\
\hline 7 & 9 & 9 \\
\hline 8 & 8 & 8 \\
\hline 9 & 9 & 6 \\
\hline 10 & 9 & 7 \\
\hline
\end{tabular}

Table 4: Thickness of 10 tablets $(\mathrm{mm})$

\begin{tabular}{|c|c|c|c|c|}
\hline No. of tablets & $\begin{array}{c}\text { Average } \\
\text { thickness } \\
(\mathbf{m m})\end{array}$ & Standard deviation & Upper limit & Lower limit \\
\cline { 2 - 5 } & $\mathbf{( X + 3 S )}$ & $\mathbf{( X - 3 S )}$ \\
\hline Qsartan & 8.1 & 1.28 & 11.94 & 4.26 \\
\hline Losartan & 8 & 1.24 & 11.72 & 4.28 \\
\hline \multicolumn{5}{|c}{ Table 5: Statistical thickness } \\
\hline \multicolumn{5}{|c}{} \\
\hline
\end{tabular}

\begin{tabular}{|c|c|c|}
\hline Number of sample & Qsartan $\mathbf{( k g )}$ & Losartan $\mathbf{k g})$ \\
\hline 1 & 6.66 & 7.27 \\
\hline 2 & 5.74 & 7.16 \\
\hline 3 & 6.40 & 7.05 \\
\hline 4 & 7.30 & 6.88 \\
\hline 5 & 5.64 & 6.65 \\
\hline 6 & 5.97 & 6.46 \\
\hline 7 & 5.55 & 6.36 \\
\hline 8 & 6.23 & 6.40 \\
\hline 9 & 6.80 & 6.23 \\
\hline 10 & 6.21 & 6.14 \\
\hline
\end{tabular}

Table 6: Hardness of 10 tablets from the optimized formulation.

\begin{tabular}{|c|c|c|c|c|}
\hline No. of tablets & $\begin{array}{c}\text { Average } \\
\text { hardness } \\
(\mathbf{k g})\end{array}$ & $\begin{array}{c}\text { Standard } \\
\text { deviation }\end{array}$ & $\begin{array}{c}\text { Upper limit } \\
(\mathbf{X + 3 S})\end{array}$ & $\begin{array}{c}\text { Lower limit } \\
(\mathbf{X}-3 \mathbf{3})\end{array}$ \\
\hline Qsartan & 6.25 & 0.55 & 7.9 & 4.6 \\
\hline Losartan & 6.66 & 0.40 & 7.86 & 5.46 \\
\hline
\end{tabular}

Table 7: Statistical hardness calculation.

\begin{tabular}{|c|c|c|c|}
\hline Tablets & $\begin{array}{c}\text { Friability } \\
\mathbf{( \% )}\end{array}$ & $\begin{array}{c}\text { BP/USP } \\
\text { specification }\end{array}$ & $\begin{array}{c}\text { Deviation from BP/USP } \\
\text { specification }\end{array}$ \\
\hline Qsartan & $0.65 \%$ & Not more than $1 \%$ & Within the specified limit \\
\cline { 1 - 3 } Losartan & $0.035 \%$ & Within the specified limit \\
\hline
\end{tabular}

Table 8: Friability test.

\begin{tabular}{|c|c|c|c|}
\hline Tablet & $\begin{array}{c}\text { Disintegration time } \\
\text { (min) }\end{array}$ & Limits & $\begin{array}{c}\text { Deviation from } \\
\text { USP }\end{array}$ \\
\hline Qsartan & 10.25 & Not more than 60 min for & PASS \\
\cline { 1 - 2 } Losartan & 20 & coated tablets & PASS \\
\hline
\end{tabular}

Table 9: Disintegration test.

\section{References}

1. Naveed S (2014) Analytical Method for Estimation of Losartan by using UVSpectrophotometer. Global Journal of Medical Research; 14 version 1.0.

2. Ashraf Z, Waheed N, Naz E, Ahmed F, Asim T, et al. (2015) Assay for Quantitative Analysis of Losartan Potassium by using UV Spectroscopy. Global Journal of Medical Research; 15 Version 1.0.

3. Katzung BG, Masters SB, Trevor AJ (2012) Antihypertensive agent: Basic and clinical pharmacology (12 ${ }^{\text {th }}$ edn.) Lange Medical Publications, USA 3: 185.

4. Boersma C, Atthobari J, Gansevoort R, de Jongvan den Berg L, de Jong $P$, et al. (2006) Pharmacoeconomics of angiotensin II antagonist in type 2 diabetic patients with nephropathy: Implications for decision making. Pharmacoeconomics 24: 523-535.

5. Kirk JK (1999) Angiotensin-II receptor antagonists: Their place in therapy. Am Fam Physician 59: 3140-3148.

6. Hernández HR, Canache BS, Velasco M, Armas-Hernández MJ, ArmasPadilla MC, et al. (2002) Angiotensin II receptor antagonists role in arterial hypertension. J Hum Hypertens 16: s93-s99.

7. Goa KL, Wagstaff AJ (1996) Losartan potassium: a review of its Pharmacology Clinical Efficacy and Tolerability in the Management of Hypertension. Drugs 51: 820-845.

8. Shanmugam $S$, Chakrahari R, Sundaramoorthy $K$, Ayyappan $T$, Vetrichelvan $T$ (2011) Formulation and Evaluation of Sustained Release Matrix Tablets of Losartan potassium. Int J Pharm Tech Res 3: 526-234.

9. Brenner BM, Cooper ME, de Zeeuw D, Keane WF, Mitch WE, et al. (2001) Effects of Losartan on Renal and Cardiovascular Outcomes in Patients with Type 2 Diabetes and Nephropathy. N Engl J Med 345: 861-869. 